\title{
Gravity anomaly and interpretation map of the Chignik and Sutwik Island quadrangles, Alaska
}

By

\author{
J. E. Case, David F. Barnes, R. L. Detterman, \\ Robert L. Morin, and Robert F. Sikora
}

\section{Introduction}

The gravity field of the Chignik and Sutwik Island quadrangles near the center of the Alaska Peninsula represents a complex series of transitions between probable continental crust on the north, probable oceanic crust on the south, sedimentary basins on each side of the peninsula, and a central structural high and volcanic arc. The resulting gravity field may be generalized as a central southwest- to northeast-trending gravity high bordered on both sides by flanking gravity lows over sedimentary basins underlying the lowlands and continental shelf. All three gravitational features show discontinuities and magnitude variations that reflect the complex geologic setting.

Data concerning this complex gravity field have accumulated slowly and intermittently since an initial measurement was made at Port Heiden more than 25 years go (Thiel and others, 1958, 1959). A few reconnaissance measurements by R. V. Allen and an offshore traverse conducted by the U.S. Coast and Geodetic Survey R/V Surveyor were made in the early 1960's (Barnes and others, 1966; Barnes, 1967). At about the same time, Gulf Oil Corp. contracted for a relatively detailed survey of the lowlands on the north shore of the peninsula; the map prepared from this survey is now available (Gulf Oil Corp., Port Moller Development Contract Report, available at U.S. Geological Survey, Anchorage, Alaska). In the early 1970 's, a few new land measurements were made by P. L. Dobey, of the Alaska Division of Geological and Geophysical Surveys, and an offshore traverse was completed by the R/V C. Greene on contract to the U.S. Geological Survey (Fisher, 1979, and M. A. Fisher, written commun., 1977). The most recent measurements, the basis for this map, were made by M. E. Yount, D. L. Detra, D. R. Jefferis, and J. E. Case during the mineral assessment of the two quadrangles. D. F. Barnes, R. L. Morin, D. R. Jefferis, and R. F. Sikora have shared in the data compilation. Geologic background for the text was provided by R. L. Detterman, T. P. Miller, E. Young, and F. H. Wilson (1979, 1981).

\section{Gravity data}

The gravity data were obtained with both temperature-compensated and thermostatically controlled gravimeters; most instruments were used in loops of 1 to 2 days' duration. More of the 60 percent of the measurements were tied to base stations at either Chignik Lagoon or Port Heiden. The Chignik Lagoon base (designated CHLC) is located at the door of the main cookhouse of Columbia Ward Fisheries, where the established gravity is $981,656.80 \mathrm{mGal}$ on the IGSN datum. The Port Heiden base (HEIT) is located on the south corner of the concrete step to the air terminal from the aircraft loading apron, where the established gravity value is $981,671.88 \mathrm{mGal}$. Supplementary bases were established in these towns and in Anchorage Bay and Black Lake; several otherstations may be reoccupiable, though poorly tied to the Alaskan gravity base network (Barnes, 1968). Offshore data were obtained using LaCoste \& Romberg shipborne gravimeters (Barnes, 1977, Fisher, 1979).

Elevations for stations along the coastline were obtained from the sea level datum corrected for tidal variation and are probably correct to within $1 \mathrm{~m}$. In the interior, altimetry was used for most of the elevation control; bench marks, spot elevations, and contour interpolation provided a few of the elevation measurements. The Alaska Peninsula frequently experiences windy and foggy climatic conditions that seriously reduce the accuracy of altimetry. Altimetric errors of 10-20 m are probably common; in very bad weather, errors may be greater than $50 \mathrm{~m}$. In analyzing the data, both altimeter and map-derived elevations have been considered, and personal judgment was used to either choose the elevation that provided the most reasonable contours or discard stations whose anomalies seemed too inconsistent with nearby stations. Although the accuracy of the land elevations is probably highly variable, few errors larger than about $30 \mathrm{~m}$, the equivalent of about half the $10 \mathrm{mGal}$ contour interval, remain on the map.

Drift corrections and routine gravity reductions were made using standard methods for Alaskan gravity data (Barnes, 1977), modernized to include use of the 1967 Geodetic Reference System ellipsoid and the IGSN-71 gravity datum. Contours for land stations are simple Bouguer anomalies for a reduction density of $2.67 \mathrm{~g} / \mathrm{cm}^{3}$. Control of the 0 and $-10-\mathrm{mGal}$ contours on the north side of the Alaska Peninsula was influenced by the Gulf Oil Corp. map of the Bristol Bay lowland, which was compiled with a reduction density of about $2.25 \mathrm{~g} / \mathrm{cm}^{3}$, but the elevations are so low that this difference is considered negligible. No terrain corrections were made or required for the lowland stations. In mountainous areas, terrain corrections would make the gravity values more positive by as much as 2 to $10 \mathrm{mGal}$ and even more for several stations.

Offshore contours are free-air anomalies, which would be 5 to $15 \mathrm{mGal}$ higher if converted to Bouguer anomalies for the water depths measured along the ship traverses.

\section{Geologic setting}

Geologic descriptions of the Chignik and Sutwik Island quadrangles are given in map reports by Detterman and others $(1979,1981)$ and Burk (1965); the generalized stratigraphy is summarized on figure 1 . Scanty offshore data are summarized in Fisher (1979). This segment of the Alaska Peninsula is dominated by three large Quaternary volcanic complexes centering at Mount Veniaminof, Black Peak, and Aniakchak Crater. Thick sequences of Tertiary marine and nonmarine sedimentary rocks occur in one or more basins along the Bristol bay side of the peninsula and in splay basins or synclines that occur near Mount Veniaminof and Aniakchak Crater. Lower Tertiary volcanic and hypabyssal rocks with interstratified sedimentary rocks are exposed discontinuously throughout much of the mountainous part of the area and on many of the offshore islands. Cretaceous continental and marine strata and Jurassic marine strata, mainly of shelf or upper slope facies, are exposed in complexly faulted anticlines in several belts that trend northeast from Chignik Lake and Aniakchak Crater. Folding in the area tends to be broad and open. The main deformational event in the area occurred after deposition of the Bear Lake Formation (Miocene) (fig. 1). Most faults are high angle, and reverse faults are common in the vicinity of Chignik anticline.

Tertiary plutons, dioritic to granitic, occur throughout the area. Copper and molybdenum mineralization of the porphyry type is associated with some of these intrusives. 


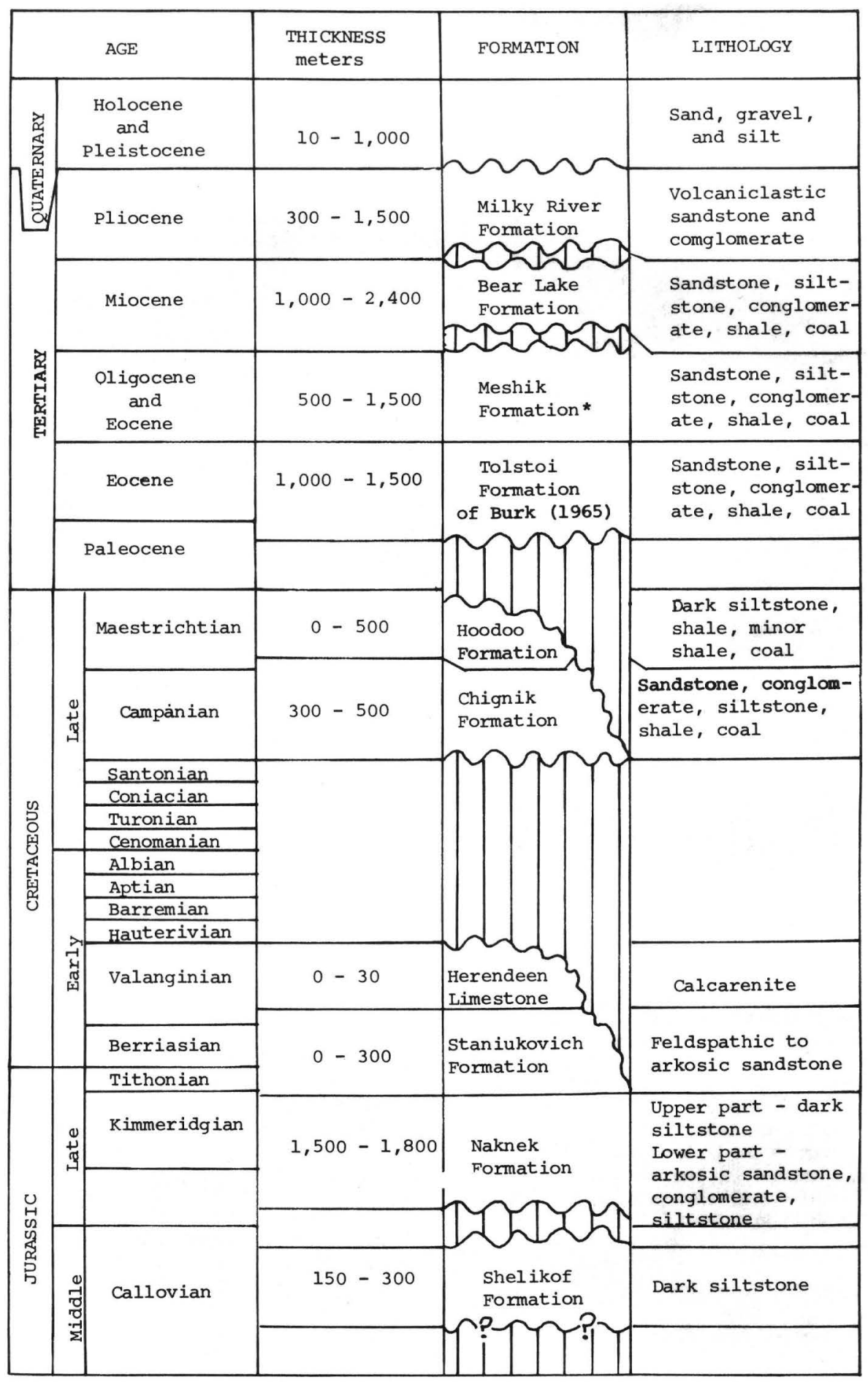

* Recent potassium-argon and fossil data indicate that the age of the Meshik Formation, shown as oligocene and Miocene by Detterman, Miller, Yount, and Wilson (1979), is Eocene and oligocene (Detterman and others, 1981).

Figure 1.-Summary of thickness, lithology, and age of major rock units in the Chignik and Sutwik Island quadrangles. Modified from Wilson (1980b) and Detterman and others (1981) 
Maps and discussions of geochemical anomalies of the area are provided in a series of reports by Detra and other workers (Detra and others, 1978a,b, Detra and Cooley, 1980a,b; Detra and Day, 1980; Detra and Hopkins, 1980; Detra and O'Leary, 1980). A map compilation of appraisal of mineral resources of the area has been prepared by Cox and others, (1981) and a report on the energy resources is being prepared by R. L. Detterman and others. Isotopic ages are given in a series of reports by Wilson $(1978,1980 a, b)$.

Densities.-A few measurements show that the densities of the Mesozoic and Cenozoic rocks are somewhat variable. For the less-altered Tertiary igneous rocks of mafic to intermediate composition, the densities of 22 samples range from 2.73 to $2.99 \mathrm{~g} / \mathrm{cm}^{3}$ and average $2.83 \mathrm{~g} / \mathrm{cm}^{3}$, densities of 19 intermediate to silicic samples range from 2.56 to 2.71 $\mathrm{g} / \mathrm{cn}^{3}$. Younger Cenozoic sedimentary rocks are probably of low density, estimated at 2.2 to $2.4 \mathrm{~g} / \mathrm{cm}^{3}$ as judged by their low degree of induration.

\section{Major features of the gravity anomaly map}

The gravity anomaly map is dominated by northeasttrending gravity highs having values of +30 to more than +50 $\mathrm{mGal}$ over the mountainous part of the Alaska Peninsula. A relative gravity low having values of 0 to $-10 \mathrm{mGal}$ occurs over the Bristol Bay Basin in the Bristol Bay lowlands (informally termed). Separating the gravity low of the Bristol Bay lowlands from the high over the mountainous parts of the peninsula is a major northeast-trending zone of steepened gravity gradient that reflects a major tectonic boundary of late Tertiary age and may represent a rejuvenated feature as old as Jurassic (Bruin Bay fault), as discussed below. From the positive anomaly over the peninsula, gravity values decrease southward to $+20 \mathrm{mGal}$ near the eastern edge of the map area. Just southeast of the map area, over the Shumagin Basin, which contains as much as $2 \mathrm{~km}$ of stratified sedimentary rocks, Bruns and Von Huene (1977) reported a gravity low of about $-20 \mathrm{mGal}$.

\section{Bristol Bay Lowlands}

Low gravity values on the north side of the Alaska Peninsula are produced by the very thick sections of lowdensity sedimentary rocks in the Bristol Bay sedimentary basin. The gravity map of Alaska (Barnes, 1977) indicates that the lowest Bouguer anomalies and probably greatest thickness of sedimentary rocks occur north of the study area in the Ugashik quadrangle. There the gravity minimum slightly southeast of the coastline suggests that the deepest part of the basin is onshore; but in the Chignik-Sutwik area, it is probably close to the coastline or possibly slightly offshore. The lack of offshore data makes it impossible to estimate the magnitude of the residual gravity low or to determine the regional gradient. The $30-$ to $40-\mathrm{mGal}$ gradient along the southeast edge of the basin is partly influenced by high gravity values associated with the central peninsula and Chignik anticline; only 20 to $30 \mathrm{mGal}$ of the amount is associated with the sedimentary section. Good density data are lacking, but both seismic and drill-hole data provide information about the sedimentary thicknesses involved.

In the southwest part of the Bristol Bay lowlands, the Gulf Oil Corp. \#1 Sandy River drill hole penetrated about $3,940 \mathrm{~m}$ of sedimentary rocks, terminating in the Stepovak Formation (of Burk (1965); Oligocene) (Alaska Geological Society, 1975). Basalt flows and tuff beds were penetrated in shallow parts of the well, and intercalated volcanic rocks are common below $3,650 \mathrm{~m}$. To the northeast, the Gulf Oil Corp. \#1 Port Heiden drill hole terminated in granite, presumably of Jurassic and(or) Cretaceous age (Alaska Geological Society, 1975; Reed and Lanphere, 1973), at a depth of about $4,550 \mathrm{~m}$, after penetrating Tertiary sedimentary and volcanic rocks. Abundant volcanogenic materials were penetrated at a depth of $2,740 \mathrm{~m}$ and persisted to the top of granite at 4,550 m.

Tertiary sedimentary and volcanic rocks of low mean density, 3,950 to $4,550 \mathrm{~m}$ thick, are the evident source of the relative gravity low of $30 \mathrm{mGal}$ or more that occurs over the Bristol Bay lowlands. Density contrasts of $0.2-0.3 \mathrm{~g} / \mathrm{cm}^{3}$ or more are expected between the thick younger Tertiary sedimentary sequence in the basin and the older Mesozoic to Tertiary sequence to the southeast.

The axis of the main Bristol Bay Basin approximately coincides with, or parallels, the northwest coastline, but the magnitude of the anomaly varies along the axis of the basin. This variation could represent either depth differences or variations in lithologic character, particularly in percentage of volcanic material, along the basin. South of Port Heiden, for example, a northward bend of the 0 -mGal contour across the coastline suggests a local gravity high of a few mGal magnitude, which may indicate a broad basement high.

The gravity contours also suggest two splays of the basin toward the east and south over the gravity high that borders its southeast edge. South and east of Aniakchak Crater, the bordering high is interrupted by a low indentation along the Meshik River, a major synclinal splay basin off the Bristol Bay lowlands. Depending on the configuration assumed for a "regional" gradient, a residual low of as much as $20 \mathrm{mGal}$ occurs along the Meshik River basin. As much as $3,000 \mathrm{~m}$ of low-density Tertiary material may occur in this splay basin. Another splay basin might underlie Mount Veniaminof, which is marked by a distinct gravity low. This low could represent either the absence of terrain corrections, a thick accumulation of low-density volanic material, an underlying sedimentry section, or some combination of these factors. The geologic map shows that a thick section composed of the Bear Lake Formation of Miocene age crops out south of Mount Veniaminof. The central closure within the low may be entirely attributable to the accumulation of snow and ice within the crater. A single measurement on this snow and ice gives an anomaly approximately 10 to $20 \mathrm{mGal}$ (depending on altimetry adjustments) lower than a nearby station on the crater rim, a difference suggesting that the snow and ice within the crater is at least 100 to $250 \mathrm{~m}$ thick. However, measurements on the flanks of the volcano also gave anomalies lower than those measured along the trend of high gravity that borders the Bristol Bay lowland on the southeast. Terrain corrections will raise these anomalies, but a residual low could reflect either low-density volcanic material or an underlying sedimentary basin. Aniakchak Crater and Black Peak, the other two large Quaternary volcanoes within the quadrangle, are not represented by gravity lows; no measurements are available from the other high Quaternary volcanoes on the peninsula.

\section{Axial positive anomalies}

Southwest of Mount Veniaminof, a positive gravity nose having values greater than $+50 \mathrm{mGal}$, is the northest end of a major gravity high that extends far to the southwest along the Alaska Peninsula and continues into the Aleutian Islands, (Barnes, 1977). Values to the southwest exceeding $+80 \mathrm{mGal}$ strongly suggest that the crust is oceanic rather than continental, as discussed below.

A second major gravity high coincides very closely with the Chignik anticline. Structural relief at the approximate base of the Tertiary section, across the southeast flank of the anticline, is as much as $3,000 \mathrm{~m}$ from Castle Bay to the anticlinal crest (Burk, 1965, fig. 22), and structural relief from the Port Heiden well in the Bristol Bay lowlands to the crest of the anticline (where Jurassic strata are exposed) is at least $5,500 \mathrm{~m}$ and may be $7,500 \mathrm{~m}$ or more. Here, too, simple Bouguer anomalies exceeding $+50 \mathrm{mGal}$ are suggestive of oceanic rather than continental crust, especially where the stations are in mountainous terrain, as discussed below. An isolated gravity high near the head of Aniakchak Bay may be part of the same anticlinal trend.

The major gravity gradient that trends northeast between the basin of the Bristol Bay lowlands and the structurally high area of the peninsula may represent a concealed segment of the Bruin Bay fault (see Burk, 1965, part 3), rejuvenated following the deposition of the Bear Lake Forma- 
tion (Miocene). However, the main Bruin Bay fault was upthrown on the northwest side during the Jurassic, whereas now the northwest side is structurally down.

A small northeast-trending low of about $5 \mathrm{mGal}$ in Tps. 38 and 39 S., Rs. 52 and 53 W., crosses the valley of Aniakchak River and may coincide with a synclinorium formed of Tertiary volcanic and sedimentary rocks that Burk (1965) considered to be a part of the Meshik River syncline. The axis of the poorly defined high east of Aniakchak Crater, termed the Aniakchak anomaly, trends roughly northeast, coinciding with areas of Mesozoic sedimentary rocks presumably exposed in the core of another northeast-trending anticlinorium (see Burk, 1965, part 2, sheet 1).

A small high and low in the northeast part of the area, near Cape Kuyuyukak and Nakaliliok Bay, are "one station" anomalies that may represent effects of terrain or errors in elevation and should be discounted until more detailed surveys are made.

An anomaly in an area of potential mineral resources is the negative anomaly of $10-15 \mathrm{mGal}$ in the Warner BayDevils Bay-Kuiukta Bay region in the south-central part of the map area that largely coincides with the complex of granitoid plutonic rocks of the area. These granitoid rocks have copper and molybdenum mineralization at several localities, especially at Warner Bay. It is evident that these rocks, which have been altered, are less dense than the adjacent rocks they intrude; wall rocks include considerable amount of hornfels. An aeromagnetic low occurs over some areas of alteration (Case and others, 1981). The geophysical anomalies here possibly should be considered as reconnissance regional ore guides for resource appraisals.

Scanty offshore gravity data southeast of the peninsula indicate two anomalies near the eastern margin of the area: a residual positive anomaly of about $20 \mathrm{mGal}$ northwest of the Semidi Islands and a large negative anomaly of $30 \mathrm{mGa}$ or more east of Sutwik Island. The positive anomaly may represent a locally dense or shallow segment of the KenaiKodiak Ridge described by Fisher (1979). The negative anomaly probably represents low-density sedimentary deposits in the southern part of a Tertiary basin extending southwestward from Shelikof Strait, where reflection profiles show as much as $1.5 \mathrm{~km}$ of layered strata above an acoustic basement (Fisher, 1979, fig. 4).

Several prominent zones of steepened magnetic gradient trend northwest across the area (Case and others, 1981). Some of these zones coincide with mapped faults; others appear to be related to concealed features in the subsurface. The reconnaissance gravity data of this report contain only a few enigmatic hints of possible northwest-trending features, for example, the interruption of the gravity high near Mount Veniaminof along a northwest trend. Possibly other trends will become evident when more detailed surveys and terrain corrections are made.

\section{Some regional crustal inferences}

As no deep crustal refraction measurements have been carried out in this part of Alaska, the gravity data provide the only basis for speculation about crustal composition and thickness. The strongly positive gravity anomalies, greater than $+50 \mathrm{mGal}$, over the Aleutian Islands extend northeast along the Alaska Peninsula to about lat. $58^{\circ}$ N., near Becharof Lake, in the Ugashik quadrangle. A major negative anomaly in the vicinity of Katmai National Park continues northeastward into Cook Inlet and beyond to the Matanuska Valley (Barnes, 1977) and may indicate "transitional" or continental crust. Empirical relationships between crustal density, seismic velocities determined from refraction profiles, and crustal thickness have been studied by numerous authors, including Woollard (1959), Talwani, and others (1959), Woollard and Strange (1962), Demenitskaya and Belyaevsky (1969) and others. Two examples of gravity models tied to refraction data across volcanic ares are profiles across the Central Aleutian arc by Grow (1973) and across the Lesser
Antilles volcanic are by Bowin (1976). There refraction data and strongly positive gravity anomalies indicate that the crystalline crust is thickened to greater amounts than that of typical oceanic crust, and the seismic velocities of the lower crust are more similar to oceanic crust than continental, even though thick sedimentary layers are present in the shallower portions. For land areas, where Bouguer anomalies exceed +50 mGals, oceanic or "transitional" crust is suspected. Anomalies greater than +50 mGals were used by Case and others (1971) to postulate oceanic crust on land in western Colombia, and the inferences from gravity data were substantiated by subsequent refraction studies of Project Narino (see summary by Case, 1980).

Deep refraction lines both parallel to and normal to the regional tectonic grain are needed to resolve such questions of crustal properties in this area of high seismic risk, active volcanism, and large resource potential for oil and gas and metallic minerals.

\section{Acknowledgments}

Gravity surveys were conducted by R. V. Allen, David Jefferis, Carlene Holloway, Elizabeth Yount, and David Detra in addition to authors of this report. We are grateful for marine data provided by Michael Fisher for the cruise of the R/V C. Greene in 1975.

\section{References}

Alaska Geological Society, 1975, Bristol Bay region: strtigraphic correlation section, southwest Alaska: Alaska Geological Society, chart.

Barnes, D. F., 1967, Four preliminary gravity maps of Alaska: U.S. Geological Survey Open-File Report.

1968, Alaskan gravity base station network: U.S. Geological Survey Open-File Report, 55 p. 1972 , Notes on the processing and presentation of U.S. Geological Survey Alaskan gravity data: U.S. Geological Survey Open-File Report, 25 p.

1976, Bouguer gravity map of Alaska: U.S. Geological Survey Open-File Report 76-70, scale 1:2,500,000. 1977, Bouguer gravity map of Alaska: U.S. Geological Survey Geophysical Investigations Map GP-913, scale $1: 2,500,000$.

Barnes, D. F., Lucas, W. H., Mace, E. V., and Malloy, R. J., 2966, Reconnaissance gravity and other geophysical data from the continental end of the Aleutian arc abs. : American Association of Petroleum Geologists Bulletin, v. 50 , no. 3 , p. 644 .

Bowin, Carl, 1976, Caribbean gravity field and plate tectonics: Geological Society of America Special Paper $169,79 \mathrm{p}$.

Bruns, T. R., and von Huene, Roland, 1977, Sedimentary basins on the Shumagin Shelf, western Gulf of Alaska: Offshore Technology Conference, 9th, Houston,Tex., 1977, Proceedings, p. 41-50.

Burk, C. A., 1965, Geology of the Alaska Peninsula-island arc and continental margin: Geological Society of America Memoir 99, 250 p.

Case, J. E., 1980, Crustal setting of mafic and ultramafic rocks and associated ore deposits of the Caribbean region: U.S. Geological Survey Open-File Report 80$304,95 \mathrm{p}$.

Case, J. E., Cox, D. P., Detra, David E., Detterman, R. L., and Wilson, F. H., 1981, Maps showing aeromagnetic survey and geologic interpretation of the Chignik and Sutwik Island quadrangles, Alaska: U.S. Geological Survey Miscellaneous Field Studies Map MF-1053-B, 2 sheets, scale $1: 250,000$.

Case, J. E., Duran, S., L. G., Lopez R., A., and Moore, W. R., 1971, Tectonic investigations in western Colombia and eastern Panama: Geological Society of America Bulletin, v. 82, p. 2685-2711.

Cox, D. P., Detra, D. E., and Detterman, R. L., 1981, Mineral resource maps of the Chignik and Sutwik Island quadrangles, Alaska: U.S. Geological Survey Miscellaneous Field Studies Map MF-1053-K, 2 sheets, scale 1:250,000. 
Demenitskaya, R. M., and Belyaevsky, N. A., 1969, The relation between the Earth's crust, surface relief, and the gravity field in the USSR, in Hart, P. J., ed., The Earth's crust and upper mantle: American Geophysical Union Monograph 13, p. 312-319.

Detra, D. E., Cooley, E. F., Day, G. W., O'Leary, R. M., Holloway, C. D., and Yount, M. E., 1978a, Results and statistical summary from analysis of stream-sediment and heavy-mineral-concentrate samples, Chignik and Sutwik Island quadrangles, Alaska: U.S. Geological Survey Open-File Report 78-234, 96 p.

Detra, D. E., Cooley, E. F., Hopkins, R. T., Jr., O'Leary, R. M., Jefferis, D. R., $1978 \mathrm{~b}$, Final results and statistical summary from analysis of stream-sediment and heavymineral-concentrate samples, Chignik and Sutwik Island quadrangles, Alaska: U.S. Geological Survey Open-File Report 78-1090, 105 p.

Detra, D. E., and Cooley, E. F., 1980a, Distribution and abundance of copper in minus-80-mesh stream-sediment and nonmagnetic heavy-mineral-concentrate samples, Chignik and Sutwik Island quadrangles, Alaska: U.S. Geological Survey Miscellaneous Field Studies Map MF1053-C, 2 sheets, scale 1:250,000.

$1980 \mathrm{~b}$ Distribution and abundance of bismuth,tin, and tungsten in nonmagnetic heavy-mineral-concentrate samples, Chignik and Sutwik Island quadrangles, Alaska: U.S. Geological Survey Miscellneous Field Studies Map MF-1053-H, 1 sheet, scale 1:250,000.

Detra, D. E., and Day, G. W., 1980, Distribution and abundance of molybdenum in minus-80-mesh stream-sediment and nonmagnetic heavy-mineral-concentrate samples, Chignik and Sutwik Island quadrangles, Alaska: U.S. Geological Survey Miscellaneous Field Studies Map MF-1053-F, 2 sheets, scale $1: 250,000$.

Detra, D. E., and Hopkins, R. T., Jr., 1980, Distribution and abundance of lead in minus-80-mesh stream-sediment and nonmagnetic heavy-mineral-concentrate samples, Chignik and Sutwik Island quadrangles, Alaska: U.S. Geological Survey Miscellaneous Field Studies Map MF1053-D, 2 sheets, scale $1: 250,000$.

Detra, D. E., and O'Leary, R. M., 1980, Distribution and abundance of zinc in minus-80-mesh stream-sediment and nonmgnetic-heavy-mnineral concentrate samples, Chignik and Sutwik Island quadrangles, Alaska: U.S. Geological Survey Miscellaneous Field Studies Map MF1053-E, 2 sheets, scale 1:250,000.

Detterman, R. L., Miller, T. P., Yount, M. E., and Wilson, F. H., 1979, Generalized geologic map of Chignik and Sutwik Island quadrangles, Alaska: U.S. Geological
Survey Miscellaneous Field Studies Map MF-1053-A, scale $1: 250,000$.

1981, Geologic map of the Chignik and Sutwik Island quadrangles, Alaska: U.S. Geological Survey Miscellaneous Geologic Investigations Map I-1229, scale $1: 250,000$ in press .

Fisher, M. A., 1979, Structure and tectonic setting of continental shelf southwest of Kodiak Island, Alaska: American Association of Petroleum Geologists Bulletin, v. 43 , no. 3 , p. 301-310.

Grow, J. A., 1973, Crustal and upper mantle structure of the Central Aleutian arc: Geological Society of America Bulletin, v. 84, p. 2169-2192.

Talwani, Manik, Sutton, G. H., and Worzel, J. L., 1959, A crustal section across the Puerto Rico Trench: Journal of Geophysical Research, v. 64, no. 10, p. 1545-1555.

Thiel, E., Ostenso, N. A., Bonini, W. E., and Woollard, G. P., 1958, Gravity measurements in Alaska: Woods Hole Oceanographic Institute Technical Report Ref. 58-54, $104 \mathrm{p}$.

Thiel, E., Ostenso, N. A., Bonini, W. E., and Woollard, G. P., 1959, Gravity measurements in Alaska: Arctic, Journal of the Arctic Institute of North America, v. 12, no. 2, p. 66-76.

Wilson, F. H., 1978, Map showing preliminary results of $\mathrm{K}-\mathrm{Ar}$ studies in the Chignik and Sutwik Island quadrangles, Alaska: U.S. Geological Survey Open-File Report 781064.

1980a, Late Mesozoic and Cenozoic tectonics and the age of porphyry copper prospects, Chignik and Sutwik Island quadrangles, Alaska Peninsula: Dartmouth College, Hanover, N.H., Ph.D. dissertation, p.

1980 b, Late Mesozoic Cenozoic tectonies and the age of porphyry copper prospects; Chignik and Sutwik Island quadrangles, Alaska Peninsula: U.S. Geological Survey Open-File Report 80-543.

Woollard, G. P., 1959, Crustal structure from gravity and seismic measurements: Journal of Geophysical Research, v. 64 , no. 10 , p. 1521-1544.

Woollard, G. P., Ostenso, N. A., and Thiel, E., 1960, Gravity anomalies, crustal structure, and geology in Alaska: Journal of Geophysical Research, v. 65, no. 3, p. 10211037.

Woollard, G. P., and Strange, W. E., 1962, Gravity anomalies and crust of the Earth in the Pacific basin, in MacDonald, G. A., and Kuno, Hisashi, eds., The crust of the Pacific basin: American Geophysical Union Geophysical Monograph 6, p. 60-80. 